\title{
Studies on Biochemical Composition of Various Tomato (Solanum lycopersicum L.) Genotypes
}

\author{
Anupama Lakra*, Jitendra Trivedi and Sunidhi Mishra \\ Department of Vegetable Science, Indira Gandhi Krishi Vishwavidyalaya, \\ Raipur, 492012-India \\ *Corresponding author
}

\begin{abstract}
A B S T R A C T
\end{abstract}
Keywords

Tomato, Biochemical composition, Pigments, Reducing and Non-reducing sugar

Article Info

Accepted:

10 November 2018

Available Online:

10 December 2018
An experiment was carried out to study biochemical composition of different genotypes of tomato. A total of 22 genotypes were studied in which significant differences were observed for various biochemical traits among the genotypes. Genotype 2014/TODVAR-3 showed highest $\beta$-carotene $(\mathrm{mg} / 100 \mathrm{ml})$ and lycopene content $(\mathrm{mg} / 100 \mathrm{ml})$, whereas genotype 2015/TOCVAR-3, showed highest chlorophyll a $(\mathrm{mg} / 100 \mathrm{ml})$ and b. Genotype 2015/TOINDVAR-5 showed highest total carotenoid (mg/100 g). Highest Ascorbic acid $(\mathrm{mg} / 100 \mathrm{~g})$, titrable acidity $(\%)$ and $\mathrm{pH}$ was observed in the genotype 2014/TODVAR-5, 2015/TOCVAR-5 and 2015/TOCVAR-3, respectively. The highest TSS percent (\%) was recorded in genotype 2015/TOCVAR-5 on the other hand genotype2015/TOINDVAR-5 gave highest total sugar (\%) and reducing sugar (\%), and 2015/TOINDVAR-4 gave highest non-reducing sugar (\%).

\section{Introduction}

Vegetables are important component of balanced human diet. Advanced production technologies are being followed to measure productivity and quality of produce. Tomato occupies a prime position in list of protective vegetable fruits since it is a rich source of minerals, vitamins and organic acids. Tomato fruit contains high moisture and dry matter (DM) of 5-7.5\% (Davies and Hobson, 1981). The composition of dry matter in tomato consists of sugars, mainly glucose and fructose, organic acids (citric and malic acid); minerals, (N, P and $\mathrm{K}$ ), vitamins and antioxidant pigments such as lycopene; they have beneficial effects on human health. Franceschi et al., (1994) and Frusciante et al., (2000) reported that the consumption of the tomato and its products (i.e., ketchup, paste) is negatively correlated with the development of tumours in the digestive tract and prostate cancer. $\beta$-carotene is known for its provitamin $A$ activity and lutein for reduced risk of lung cancer (Sies, 1991). Vitamin C plays an important role in human health and its main 
functions are in the prevention of scurvy and maintenance of skin and blood vessels (Lee and Kader, 2000). Besides its importance for consumption, fruit acidity and total soluble solid content are vital factors in the processing industry. The acidity is related to $\mathrm{pH}$ and low $\mathrm{pH}$ of the pulp prevents the growth of microorganisms that are harmful (Carvalho, 1980), which in turn decreases the period of heating needed for sterilisation during processing (Stevens, 1972). However, the total soluble solids content (TSS) is important especially when the objective is dehydration, concentrated pulp preparation, or both (Stevens, 1972).

The antioxidant content of tomato mostly depends on both genetic and environmental factors and the ripening stage (Hart and Scott, 1995; George et al., 2004; Hallmann, 2012; Nour et al., 2013). Gupta et al., (2011) reported that tomatoes contribute to a wellbalanced healthy diet with the right proportion of vital nutrients such as minerals, vitamins, essential amino acids, sugars, lycopene and other carotenoids and dietary fibres. Tomato being acceptable to people as a food could be a source of nutrients as well as a nutraceutic in the sub-continent. Therefore present experiment was carried out to study biochemical composition of different genotypes of tomato.

\section{Materials and Methods}

The present investigation was carried out in an open field in a Randomized Block Design with three replications.

For the purpose of this research, fruits were harvested at full maturity stage. 22 genotypes of tomato were evaluated for different biochemicals i.e. lycopene, $\beta$-carotene, chlorophyll a, chlorophyll $\mathrm{b}$, total carotenoid, ascorbic acid, titrable acidity, total soluble solids $\mathrm{pH}$ and sugars.

\section{Determination of pigments $(\mathrm{mg} / \mathbf{1 0 0 m l})$}

$\beta$-carotene, lycopene, chlorophyll a and b were determined according to the method of Nagata and Yamshita (2015). It is a simple method for simultaneous determination of pigments in tomato. One gm sample of tomato was taken in a tube and $20 \mathrm{ml}$ of acetone-hexane (4:6) solution was added and then vortexing and centrifugation (3000 rpm) was done for 10 and 15 minutes respectively.

Supernatant was collected and filtered through Whatman No.4 filter paper. The absorbance of the filterate was measured at $663 \mathrm{~nm}, 645 \mathrm{~nm}$, $505 \mathrm{~nm}$ and $453 \mathrm{~nm}$ by spectrophotometer at the same time. Contents of $\beta$-carotene, lycopene, chlorophyll $\mathrm{a}$ and $\mathrm{b}$ were calculated according to the following equations:

Chlorophyll a $(\mathrm{mg} / 100 \mathrm{ml})=0.999 A 663-$ 0.0989 A645

Chlorophyll b $(\mathrm{mg} / 100 \mathrm{ml})=-0.328 A 663+$ 1.77 A645

Lycopene $(\mathrm{mg} / 100 \mathrm{ml})=-0.0458 A 663+$ 0.204 A645 + 0.372 A505 - 0.0806

$A 453 \beta$-carotene $(\mathrm{mg} / 100 \mathrm{ml})=0.216 A 663$ $1.22 A 645-0.304 A 505+0.452 A 453$

\section{Determination of Total carotenoids (mg/100 g)}

Total Carotenoids was determined according to the method of Harborne (1973). $100 \mathrm{mg}$ of fresh crushed plant tissue was taken in a tube and $10 \mathrm{ml}$ of $80 \%$ acetone was added and centrifuged at $3000 \mathrm{rpm}$ for 10 minutes. Supernatant was taken in a separate tube and volume make up was done upto a known volume of $10 \mathrm{ml}$ with $80 \%$ acetone. The optical density of supernatant was measured at $480 \mathrm{~nm}$ in UV spectrophotometer. Total Carotenoid was calculated according to the following equations: 


\section{Calculation}

Amount of total carotenoid $=$

$4 \times$ OD Value $\times$ Total volume of sample (i.e. we have made the in $100 \mathrm{mg}$ plant tissue supernatant volume as $10 \mathrm{ml}$ )

Weight of fresh plant tissue (i.e. we have taken $100 \mathrm{mg}$ plant tissue to grind)

\section{Determination of Ascorbic acids (mg/100} gm)

The ascorbic acid in fresh fruits was measured by titration against 2.6 dichlorophenolindophenol dye according to Albrecht (1993). In this experiment $10 \mathrm{ml}$ of tomato juice was taken and made up to $100 \mathrm{ml}$ with $3 \%$ HPO3 and filtered. $10 \mathrm{ml}$ of filtrate was taken with the help of pipette into a conical flask and titrate with the standard dye solution to a pink colour end-point persisting of at least 15 second titre was determined. It should be taken care that titre should not exceed 3 to $5 \mathrm{ml}$.Three parallel titrations were performed for each sample. For the calculation of L- ascorbic acid content in the tomato, the average values of the volumes of three titrations were taken.

\section{Determination of titrable acidity (\%)}

Acid content of the extracted juice of five fruits from each plot was determined by titrating $10 \mathrm{ml}$ of tomato juice against $0.1 \mathrm{~N}$ $\mathrm{NaOH}$ using phenolphthalein as an indicator. The end point appeared as light pink colour. Acidity was expressed in terms of percentage.

Determination of total soluble solids (\%), ph and sugars $(\%)$

The fruits were cut into small pieces and squeezed to obtain the juice and with the help of the ERMA hand refractometer, TSS (\%) of fruit was determined. The average was calculated and was expressed as per cent total soluble solids in juice. The $\mathrm{pH}$ of the fruit juice extracted from five randomly selected fruits from each plots was recorded with the help of $\mathrm{pH}$ meter. Sugars were determined by the method of Lane and Eynon as described by Ranganna (1997).

\section{Results and Discussion}

Significant differences were detected among tomato genotypes in all studied biochemical parameters grown under the same agricultural, geographical and climatic conditions. lycopene is a pigment, responsible for the red colour of the mature tomato and its products (Shi et al., 2000). The present data on lycopene content showed significant variations among various genotypes (Table 1), it varied between $0.028 \mathrm{mg} / 100 \mathrm{ml}$ to $0.483 \mathrm{mg} / 100 \mathrm{ml}$. The findings are in accordance with values obtained by Mladenovic et al., (2014) $0.031 \mathrm{mg} / 100 \mathrm{~g}$ to $4.330 \mathrm{mg} / 100 \mathrm{~g}$. Kumar et al., (2014) and Kaur and Chemma (2005) also found lycopene content ranged from 0.042 and $0.016 \mathrm{mg} / 100 \mathrm{gm}, 0.29$ to $3.31 \mathrm{mg} / 100 \mathrm{~g}$ fresh fruit respectively. Hammed et al., (2012) and Burns et al., (2003) also reported similar results. Lycopene is the major carotenoid found in tomatoes and in the second place in the carotenoids ranking is beta-carotene.

The content of lycopene in tomato fruits depends on many factors, including the level of nitrogen in soil. The increase in lycopene content along with more intense nitrogen fertilization is justified by Lacatus et al., (1995)as follows: nitrogen is the main element that forms Acetyl-CoA enzyme which plays a central role in the synthesis of carotenoid pigments and converts beta-carotene into lycopene. Dadomo et al., (1994) found that with the increased dose of nitrogen the yield of red and uniformly stained fruits as well as the number of fruits per unit of cultivation area were higher. 
$\beta$-carotene ranged from $0.032 \mathrm{mg} / 100 \mathrm{ml}$ $0.268 \mathrm{mg} / 100 \mathrm{ml}$ (Table 1). Results were similar as reported by Hallmann et al., (2008)that tomato fruits contained $0.26 \mathrm{mg} / 100 \mathrm{~g}$ fw of $\beta$-carotene, while in 2009 it was $0.21 \mathrm{mg} / 100 \mathrm{~g}$ fw. Kotikova et al., (2009) also reported similar results. Abushita et al., (2000) found that the $\beta$-carotene content was between $2.9 \mathrm{mg} / \mathrm{kg}-6.2 \mathrm{mg} / \mathrm{kg}$. It is believed that the differences among the contents depend upon the growing methods and climate conditions (Raffo et al., 2002), but on the traits of the researched tomato genotypes, too.

Chlorophyll a and Chlorophyll $\mathrm{b}$ ranges between $0.003 \mathrm{mg} / 100 \mathrm{ml}-0.068$ and 0.004 $\mathrm{mg} / 100 \mathrm{ml}-0.255 \mathrm{mg} / 100 \mathrm{ml}$, respectively (Table 1). Watada et al., (1976) reported that the average chlorophyll content decreased from $13.45 \mu \mathrm{g} / \mathrm{g} \mathrm{fw}$ in immature green fruit to $0.3 \mu \mathrm{g} / \mathrm{g} \mathrm{fw}$ in partially ripe fruit. In present investigation the range of total carotenoid was $0.101 \mathrm{mg} / \mathrm{g}-0.531 \mathrm{mg} / \mathrm{g}$. Raffo et al., (2006) reported that carotenoids content of tomato were very low at the breaker stage $(1.08 \mathrm{mg} / 100 \mathrm{~g})$ which increased 10 -fold during ripening and reached $12.705 \mathrm{mg} / 100 \mathrm{~g}$ at full ripening stage. The carotenoids content increased during storage in tomato because of advancement of ripening stage, chlorophyll degradation and increase in the carotenoids synthesis Prete et al., (1995). Carotenoid concentrations in fruits and vegetables were shown to vary with plant variety, degree of ripeness, time of harvest and growing and storage conditions Lessin et al., (1997). Apart from that, environmental factors such as temperature, plant nutrition, and light can also considerably affect the biosynthesis of carotenoids. There were significant differences in the amount of ascorbic acid in the different genotypes of tomatoes studied, it ranges between $2.50 \mathrm{mg} / 100 \mathrm{~g}$ to 26.50 $\mathrm{mg} / 100 \mathrm{~g}$ (Table 1). Similar results were found by Gupta et al., (2011) who studied two genotypes and reported the amount of ascorbic acid as 31.33 and $27.82 \mathrm{mg}$. Moneruzzaman $e t$ al., (2008), Rai et al., (2012), Abushita et al., (2000) and Nagar et al., (2015) also reported similar results. Gould (1992), in his recommendations for breeding varieties for processing, suggested the need for developing varieties which have ascorbic acid in excess of $20 \mathrm{mg} / 100 \mathrm{~g}$. In light of this, cherry varieties, 818 cherry, T-56 and BR-124, having high ascorbic acid may be recommended as potential varieties for processing and for improvement of nutritional value in breeding programmes. Consumption of these varieties as fresh salad may also serve as a good source of dietary antioxidant.

The level of acidity in tomato fruits is an important parameter associated with sensory attributes like flavor and astringency. Titratable acidity varied significantly between 0.35 to 0.83 per cent (Table 1 ). The results are in accordance with Manna and Paul (2012) who reported acidity ranging from 0.30 to 0.73 percent. Similar results were also reported by Nour et al., (2013), Rana et al., (2014), Rai et al., (2012) and George et al., (2004). According to Mahakun et al., (1979), the genetic factor is the major acid content determinant in tomato plant fruits, with great variation occurring between genotypes. (Stevens and Rick, 1986) these authors reported variation in fruit acidity (\% citric acid) for different accessions of Lycopersicon esculentum, from $0.40 \%$ to $0.91 \%$; Stevens et al., (1979) and Mitchell et al., (1991) found lower citric acid percentage values, down to $0.25 \%$. Loures (2001), evaluating the hybrid 'Carmem', found fruit titratable acidity (\% citric acid) of $0.46 \%$ and $0.49 \%$ under greenhouse and field conditions, respectively.

TSS is a key determinant of shelf life and quality of the crop, whether it is for the fresh produce or for processing. Furthermore, TSS levels also contribute strongly to the tomato flavor and consistency (Stevens et al., 1997). 
Table.1 Beta carotene, lycopene, chlo.a, chlo.b, total carotenoid, ascorbic acid and titrable acidity as affected by different genotypes of tomato

\begin{tabular}{|c|c|c|c|c|c|c|c|}
\hline Genotypes & $\begin{array}{l}\beta \text {-Carotene } \\
(\mathrm{mg} / 100 \mathrm{ml})\end{array}$ & $\begin{array}{l}\text { Lycopene } \\
(\mathrm{mg} / 100 \mathrm{ml})\end{array}$ & $\begin{array}{l}\text { Total } \\
\text { Carotenoids } \\
(\mathrm{mg} / \mathrm{g})\end{array}$ & $\begin{array}{l}\text { Chlo.a } \\
(\mathrm{mg} / 100 \mathrm{ml})\end{array}$ & $\begin{array}{l}\text { Chlo.b } \\
(\mathrm{mg} / 100 \mathrm{ml})\end{array}$ & $\begin{array}{l}\text { Ascorbic } \\
\text { Acid } \\
(\mathrm{mg} / 100 \mathrm{~g})\end{array}$ & Titrable Acidity (\%) \\
\hline 2013/TODVAR-1 & 0.056 & 0.055 & 0.131 & 0.010 & 0.007 & 7.83 & 0.54 \\
\hline 2013/TODVAR-3 & 0.086 & 0.267 & 0.255 & 0.007 & 0.021 & 9.67 & 0.35 \\
\hline 2014/TODVAR-1 & 0.032 & 0.051 & 0.108 & 0.004 & 0.004 & 11.17 & 0.51 \\
\hline 2014/TODVAR-2 & 0.072 & 0.159 & 0.122 & 0.007 & 0.007 & 9.00 & 0.38 \\
\hline 2014/TODVAR-4 & 0.082 & 0.132 & 0.251 & 0.003 & 0.005 & 3.83 & 0.57 \\
\hline 2014/TODVAR-5 & 0.073 & 0.121 & 0.168 & 0.011 & 0.167 & 26.50 & 0.47 \\
\hline 2014/TODVAR-6 & 0.112 & 0.118 & 0.101 & 0.048 & 0.080 & 2.50 & 0.53 \\
\hline 2015/TOCVAR-1 & 0.078 & 0.033 & 0.162 & 0.007 & 0.164 & 19.67 & 0.72 \\
\hline 2015/TOCVAR-2 & 0.103 & 0.094 & 0.238 & 0.007 & 0.009 & 7.00 & 0.70 \\
\hline 2015/TOCVAR-3 & 0.083 & 0.120 & 0.190 & 0.068 & 0.255 & 16.83 & 0.51 \\
\hline 2015/TOINDVAR-2 & 0.049 & 0.028 & 0.168 & 0.031 & 0.105 & 9.17 & 0.51 \\
\hline 2015/TOINDVAR-3 & 0.040 & 0.041 & 0.160 & 0.007 & 0.015 & 4.83 & 0.53 \\
\hline 2015/TOINDVAR-4 & 0.064 & 0.089 & 0.159 & 0.012 & 0.008 & 4.50 & 0.42 \\
\hline 2015/TOINDVAR-5 & 0.207 & 0.232 & 0.531 & 0.008 & 0.011 & 4.33 & 0.65 \\
\hline H-86 & 0.170 & 0.142 & 0.210 & 0.035 & 0.108 & 6.83 & 0.51 \\
\hline ARKA VIKAS & 0.128 & 0.071 & 0.114 & 0.016 & 0.013 & 3.50 & 0.38 \\
\hline SWARNA RATAN & 0.063 & 0.050 & 0.319 & 0.006 & 0.019 & 11.17 & 0.48 \\
\hline $\mathrm{CD}$ at $5 \%$ & 0.01 & 0.02 & 0.04 & 0.004 & 0.01 & 1.33 & 0.08 \\
\hline $\mathrm{CV}(\%)$ & 9.88 & 15.94 & 12.29 & 15.47 & 13.61 & 8.46 & 10.26 \\
\hline
\end{tabular}


Table. $2 \mathrm{pH}$, TSS, total sugar, reducing sugar, non reducing sugar, as affected by different genotypes of tomato

\begin{tabular}{|c|c|c|c|c|c|}
\hline Genotypes & $\mathrm{pH}$ & $\begin{array}{l}\text { TSS } \\
(\%)\end{array}$ & $\begin{array}{c}\text { Total } \\
\text { Sugar }(\%)\end{array}$ & $\begin{array}{l}\text { Reducing } \\
\text { sugar (\%) }\end{array}$ & $\begin{array}{c}\text { Non } \\
\text { Reducing } \\
\text { sugar }(\%)\end{array}$ \\
\hline 2013/TODVAR-1 & 3.86 & 3.19 & 3.24 & 3.17 & 0.07 \\
\hline 2013/TODVAR-2 & 4.00 & 4.80 & 3.63 & 3.26 & 0.37 \\
\hline 2013/TODVAR-3 & 4.01 & 3.89 & 3.25 & 3.15 & 0.11 \\
\hline 2014/TODVAR-1 & 3.97 & 3.73 & 3.48 & 3.32 & 0.16 \\
\hline 2014/TODVAR-2 & 3.89 & 4.68 & 3.22 & 3.13 & 0.09 \\
\hline 2014/TODVAR-3 & 4.00 & 3.80 & 3.18 & 3.03 & 0.15 \\
\hline 2014/TODVAR-4 & 3.96 & 3.83 & 3.26 & 2.93 & 0.33 \\
\hline 2014/TODVAR-5 & 3.95 & 4.28 & 3.33 & 3.06 & 0.27 \\
\hline 2014/TODVAR-6 & 4.07 & 3.99 & 3.30 & 3.00 & 0.3 \\
\hline 2015/TOCVAR-1 & 4.15 & 6.11 & 3.21 & 3.08 & 0.13 \\
\hline 2015/TOCVAR-2 & 4.46 & 5.55 & 3.25 & 3.14 & 0.11 \\
\hline 2015/TOCVAR-3 & 4.53 & 5.44 & 3.42 & 3.26 & 0.16 \\
\hline 2015/TOCVAR-5 & 3.91 & 7.14 & 3.11 & 2.91 & 0.2 \\
\hline 2015/TOCVAR-6 & 3.76 & 5.75 & 3.37 & 3.21 & 0.16 \\
\hline 2015/TOINDVAR-1 & 4.00 & 6.65 & 3.31 & 3.09 & 0.22 \\
\hline 2015/TOINDVAR-2 & 4.00 & 6.10 & 3.21 & 3.17 & 0.04 \\
\hline 2015/TOINDVAR-3 & 3.62 & 3.50 & 3.32 & 3.21 & 0.11 \\
\hline 2015/TOINDVAR-4 & 3.92 & 3.53 & 3.63 & 3.02 & 0.61 \\
\hline 2015/TOINDVAR-5 & 4.05 & 3.79 & 3.89 & 3.64 & 0.25 \\
\hline H-86 & 4.17 & 3.72 & 3.37 & 3.22 & 0.15 \\
\hline ARKA VIKAS & 3.99 & 3.95 & 2.84 & 2.70 & 0.14 \\
\hline SWARNA RATAN & 3.85 & 5.43 & 3.30 & 3.15 & 0.15 \\
\hline $\mathrm{CD}$ at $5 \%$ & 0.14 & 0.66 & 0.11 & 0.13 & 0.04 \\
\hline $\mathrm{CV}(\%)$ & 2.24 & 8.69 & 2.06 & 2.66 & 15.28 \\
\hline
\end{tabular}


TSS ranged from $3.19 \%$ to $7.14 \%$ (Table 2). The findings are in agreement with Saimbhi et al., (1995) who found total soluble solids ranged from 3.2 to 5.2 per cent; Kaur et al., (2005), George et al., (2004), and Hammed et al., (2012) also reported similar results. Tomato TSS is mostly composed of reducing sugar (Ho and Hewitt, 1986). Thus, any factor that alters sucrose synthesis (photosynthetic activity) will affect glucose and fructose accumulation in the fruits, thus altering TSS.

The observations recorded for $\mathrm{pH}$ are presented in table 2. The $\mathrm{pH}$ ranged from 3.62 to 4.53 under different genotypes. Results are close to the findings of Saimbhi et al., (1995) who reported range of $\mathrm{pH}$ from 3.7 to 4.9. Teka et al., (2013), also reported similar results. The $\mathrm{pH}$ of tomatoes is determined primarily by the acid content of the fruit that determine the product safety. Anthon et al., (2011) suggested that $\mathrm{pH} 4.4$ is the maximum desirable for safety and the optimum target $\mathrm{pH}$ should be 4.25 to ensure food safety. Paulson et al., (1974) reported that values of $\mathrm{pH}$ are crucial for processing tomatoes since values higher than 4.4 mean susceptibility of the pulp to thermophilic pathogens. Thus, $\mathrm{pH}$ values as low as possible (up to the point that it does not adversely affect taste) should be breed into tomato cultivars for industrial use (Georgelis et al., 2002).

The data regarding total sugar, reducing sugar and non-reducing sugar percent are depicted in Table 2. It shows that the range of total sugar varied between $2.84 \%$ to $3.89 \%$ in different genotypes. Results are similar with Nagar et al., (2015) and Rana et al., (2014) who reported higher total sugar content as 4.5 $\%$ and $2.5 \%$ respectively. Dorais et al., (2001) also reported similar results. Maximum reducing sugar ranged from $2.70 \%$ to $3.64 \%$, results are in accordance with Dalal et al., (1965) and Teka et al., (2013).
Non reducing sugar varied between 0.06-0.61 percent. Tsuda et al., (1999) reported that total sugar content will increase due to conversion of starch into sugars. The sugar content is the most important characteristics of tomatoes as high sugars determine sweetness and are required for best flavour Rodica et al., (2008). Wills et al., (1998) reported that, the increase in sugars renders the fruit much sweeter and more acceptable.

The chemical composition of the fruit depends on genetics, environmental factors (temperature, light, water and nutrient availability, air composition), agricultural techniques (varieties, plant growth regulators, ripening stage at harvest, training and irrigation system), and on post-harvest storage conditions (Borguini and Da Silva Torres, 2009; Maršić et al., 2011; Vinkovic Vrcek et al., 2011). The nutritional importance of tomato indicates that it is necessary to formulate breeding programme and to develop cultivars rich in antioxidant compounds, processing traits with high quality of fruit as well as yield (Dar and Sharma, 2011).

\section{References}

Abushita, A.A., H. G. Daood, H.G., Biacs, P.A. 2000. Change in Carotenoids and Antioxidant Vitamins in Tomato as a Function of Varietal and Technological Factors. J. Agric. Food Chem.48, 2075-2081

Albrecht, J. A., 1993. Ascorbic acid and retention in lettuce. J. Food. Qual.,16: 311-316.

Anthon GE, Strange ML and Barrett MD. Changes in $\mathrm{pH}$, acids, sugars and other quality parameters during extended vine holding of ripe processing tomatoes, $J$ Sci Food Agric. 2011.

Borguini RG, Da Silva Torres EAF. 2009. 
Tomatoes and tomato products as dietary sources of antioxidants. Food Rev Int. 25(4):313-325.

Burns, J., Fraser, P.D., Bramley, P.M. 2003. Identification and quantification of carotenoids, tocopherols and chlorophylls in commonly consumed fruits and vegetables. Phytochemistry, 62: 939-947.

Carvalho, V.D. 1980. Característicasquimicas e industriais do tomate. Informeagropecuario 6: 63-68.

Dadomo, M., Gainza, AM., Bussieres, P., Macua, IJ., Christou, M., Branthome, X. 1994. Influence of water and nitrogen availability on yield components of processing tomato in the European union countries. Acta. Hort. 376:271273, ISSN no. 0567-7572.

Dalal, K.B., Salunkhe, A.A., Boe and OlseN, L.E. 1965. Certain physiological and biochemical changes in developing tomato fruits. J. Food Sci., 30:504-508.

Dar RA, Sharma JP. 2011. Genetic variability studies of yield and quality traits in tomato (Solanum lycopersicum L.). Int J Plant Breed Genet 5:168-174.

Davies, J.N., and Hobson, G.E. 1981. The constituents of tomato fruit - the influence of environment, nutrition, and genotype. Critical Reviews in Food Science and Nutrition, 15: 205-280.

Dorais, M., Gosselin, A. and Papadopoulos, A.P. 2001. Greenhouse tomato fruitquality. Horticultural Review., 26:239-306.

Frusciante, L., Barone, B., Carputo, D., Ercolano, M.R., Della Roca F., and Esposito, S., 2000. Evaluation and use of plant biodiversity for food and pharmaceuticals. Fitoterapia., 71: 66-72.

Franceschi, S., Bidoli, E., La Vecchia, C., Talamini, R., D'Avanzo, B., and Negri, E., 1994. Tomatoes and risk of digestive-tract cancers. International Journal of Cancer., 59:181-184.
George, B., Kaur, C., Khurdiya, D.S. and Kapoor, H.C. 2004. Antioxidants in tomato (Lycopersicon esculentum) as a function of genotype. Food Chemistry., $84: 45-51$

Georgelis N. 2002. High fruit sugar characterization, inheritance and linkage of molecular markers in tomato. A Thesis Presented to the Graduate Scholl of the University of Florida in Partial Fulfilment of the Requirement for the Degree of Master of Sci. University of Florida. $71 \mathrm{pp}$.

Gould, W. A. 1992. Tomato production, processing and technology. Baltimore, USA: CTI Publications.

Gupta, A., Kawatra, A., and Sehgal, S. 2011. Physical-chemical properties and nutritional evaluation of newly developed tomato genotypes. Afr. J. Food Sci. Technol., Vol. 2(7): 167-172

Hallmann E. 2012. The influence of organic and conventional cultivation systems on the nutritional value and content of bioactive compounds in selected tomato types. J Sci Food Agric 92:2840-2848

Hallmann, E., Rembialkowska, E. 2008. Estimation of nutritive and sensory value of tomatoes and tomato juices from organic and conventional production. J. Res. Appl. Agric. Engng. 53 (3):88-95.

Hammed, M.A., Ibrahim, A.O., and Kosoko, A.R. 2012. Impact of ripening techniques on the biochemical and physiological changes in tomatoes (3Lobes and Big-Local Cultivars). Aust. J. Basic \& Appl. Sci., 6(9): 17-24

Harborne J.B., 1973. Phytochemical methods. Chapman and Hall, London. p-119.

Hart, D.J. and K.J. Scott, 1995. Development and evaluation of an HPLC method for the analysis of carotenoids in foods, and the measurement of the carotenoid content of vegetables and fruits commonly consumed in the UK. Food 
Chemistry, 54(1): 101-111.

Ho, L.C., Hewitt, J.D. 1986. Fruit development. In: The Tomato Crop. A Scientific Basis for Improvement. (Atherton, J.G., Rudich, J., Eds.). Chapman \& Hall, New York, USA. 201-239.

Kaur, R. and Cheema, D.S. 2005. Assessment of quality and biochemical traits of different genotypes of tomato. Haryana J. Hortic. Sci., 34 (3-4): 327-329.

Kotikova, Z., Hejtmánkova, A., Lachman, J. 2009. Determination of the Influence of Variety and Level of Maturity on the Content and Development of Carotenoids in Tomatoes. Czech J. Food Sci. Vol. 27, Special Issue

Kumar, A., Singh, B., and Tyagi, K. 2014. Physicochemical analysis of pt.et. extracted lycopene and viscosity, surface tension characterization by mansinghsurvis meter. World Journal of Pharmaceutical Research., Vol.3:778784

Lacatus, V., Botez, C., Chelu, M., Popescu, N., Voican, V. 1995. Chemical composition of tomato and sweet pepper fruits cultivated on active substrates. Acta. Hort. 412:168-175, ISSN no.05677572.

Lee, S.K., and Kader, A.A. 2000. Preharvest and postharvest factors influencing vitamin $\mathrm{C}$ content of horticultural crops. Postharvest Biology and Technology., 20: 207-220.

Lessin, W. J., Catignani, G.L., Schwartz, S.J. 1997. Quantification of cis-trans isomers of provitamin a carotenoids in fresh and processed fruit and vegetables. Journal of Agriculture and Food Chemistry, 45:3728-3732.

Loures, J.L., 2001. Estabelecimento e avaliacao do sistema de producaodenominadoFito, emestufa e campo.

Mahakun, N., Leeper, P.W., Burns, E.E.
1979. Acidic constituents of various tomato fruit types.Journal of Food Science 44, 241-244.

Manna, M. and Paul, A., 2012. Studies on genetic variability and characters association of fruit quality parameters in tomato. Hort. Flora Research Spectrum., 1 (2): 110-116.

Maršić NK, Gašperlin L, Abram V, Budič M, Vidrih R. 2011. Quality parameters and total phenolic content in tomato fruits regarding cultivar and microclimatic conditions. Turk J Agric For 35:185194.

Mitchell, J.P., Shennan, C., Grattan, S.R., May, D.M. 1991. Tomato fruit yields and quality under water deficit and salinity. Journal of American Society for Horticultural Science 116, 215-221.

Mladenovic, J., Acamovic-Dokovic, G., Pavlovic, R., Zdravkovic, M., Girek, Z., and Zdravkovic, J. 2014. the biologically active (bioactive) compounds in tomato (Lycopersicon esculentumMill.) as a function of genotype. Bulg. J.Agric. Sci., 20: 877882

Moneruzzaman, K.M., Hossain, A.B.M.S., Sani, W., and Saifuddin, M. 2009. Effect of stages of maturity and ripening conditions on the biochemical characteristics of tomato. Am. J. Biochem. \& Biotech., 4 (4): 336-344

Nagar, M.M.E., and Mekawi, E.M. 2015. Evaluation of Some Biochemical Properties in Different Tomato genotypes obtained from tissue culture technique. global journal for research analysis., Vol. 4

Nagata, M. and Yamshita, I 1992. Simple method for simultaneous determinationof chlorophyll and carotenoids in tomato fruit. J. Food Sci. Technol., 39:925-928.

Nour, V., Trandafir, I., and Ionica, M.E. 2013. Antioxidant compounds, mineral 
content and antioxidant activity of several tomato cultivars grown in southwestern Romania. Not Bot HortiAgrobo., 41(1):136-142

Paulson KN, Stevens MA. 1974. Relationships among titratable acidity, $\mathrm{pH}$ and buffer composition of tomato fruits. J. Food Sci.,; 39:254-357.

Pretel, M. T., Serrano, M., Amoros, A., Riquelme, F. and Romojaro, F. 1995. Non involvement of ACC and ACC oxidase activity on pepper fruit ripening. Post harvest Biology and Technology, 5: 295-303.

Raffo, A. C., Leonari, V., Fogliano, P., Ambrosino, M., Salucci, L., Gennaro, R., Bugianesi, F., Giuffrida and Qualgia, G. 2002. Nutritional value of cherry tomatoes (Lycopersicon esculentumcv. Naomo F1) harvested at different ripening stages. Journal of Agriculture and Food Chemistry. 50:6650-6.

Raffo, A., La Malfa, G., Fogliano, V., Maiani, G. and Quaqlia, G. 2006. Seasonal variations in antioxidant components of cherry tomatoes (Lycopersicon esculentum cv. Naomo F1). J.Food Comp. Anal., 19:11-19.

Rai, G.K., Kumar, R., Singh, A.K., Rai, P.K., Rai, M., Chaturvedi, A.K., and Rai, A.B. 2012. Changes in antioxidant and phytochemical properties of tomato (Lycopersicon esculentum Mill.) under ambient condition. Pak. J. Bot., 44(2): 667-670

Rana, N., Kumar, M., Walia, A., and Sharma, S. 2014. Tomato fruit quality under protected environment and open field conditions. International Journal of Bioresource and Stress Management., 5(3):422-426

Ranganna, S. 1997. Handbook of analysis and quality control for fruit and vegetable products. Tata McGraw Hill Publishing Co. Ltd., New Delhi.

Rodica S, Apahıdean SA, Apahıdean M,
Manitiu, Paulette L. 2008. Yield, Physical and Chemical Characteristics of Greenhouse Tomato Grown on Soil and Organic Substratum. 43rd Croatian and 3rd Int. Symposium on Agric. Opatija. Croatia, Pp. 439-443.

Saimbhi, M.S., Cheema, D.S., Singh, S. and Nandpuri, K.S. 1995. Physiochemical characteristics of some tomato hybrids. Tropical Science, 35(1): 9-12.

Shi, J. and M. L. Maguer. 2000. lycopene in tomatoes: chemical and physical properties affected by food processing. Crit. Rev. Biotechnol., 20: 293-334.

Sies, H. 1991. Oxidative stress: oxidants and antioxidants. London: Academic Press.

Stevens, M. A., Kader, A. A., AlbrightHolton, M., and Algazi, M. 1997. Genotypic variation for flavor and composition in fresh tomatoes. Journal of the American Society for Horticultural Science, 102, 680-689.

Stevens, M.A. 1972. Citrate and Malate Concentrations in Tomato Fruits: Genetic Control and Maturational Effects. Journal of the American Society for Horticultural Science., 97: 655-658.

Stevens, M.A., Kader, A.A., Albright, M. 1979. Potential for increasing tomato flavor via increased sugar and acid content. Journal of the American Society for Horticultural Science 104, 40-42.

Stevens, M.A., Rick, C.M. 1986. Genetics and breeding. In: The Tomato Crop. A Scientific Basis for Improvement. (Atherton, J.G., Rudich, J., Eds.) Chapman \& Hall, New York, USA. 34 109.

Teka, T.A. 2013. Analysis of the effect of maturity stage on the postharvest biochemical quality characteristics of tomato (Lycopersicon esculentum Mill.) fruit. Int. Res J Pharm. App Sci., 3(5): 180-186.

Tsuda, t., K. Chachin and Y. Ueda. 1999. 
Studies on keeping capacity of imported carabo mango fruit from the Philippines. J. Jap. Soc. Hort. Sci., 69: 669-674.

VinkovicVrcek I, Samobor V, Bojic M, Medic-Saric M, Vukobratovic M, Erhatic R, Horvat D, Matotan Z. 2011. The effect of grafting on the antioxidant properties of tomato (Solanum lycopersicum L.). Span J Agric Res 9(3):844-851.

Watada, A.E., Norris, K.H., Worthington,
J.T., and Massie, D.R. 1976. Estimation of Chlorophyll and Carotenoid Contents of Whole Tomato by Light Absorbance Techniques. Journal of Food Science41

Wills R, Glasson M, Graham D, Joyce D. Postharvest. 1998. An introduction to the physiology and handling of fruit, vegetables and ornamentals. $4^{\text {th }}$ edn. UNSW Press. Pp. 213.

\section{How to cite this article:}

Anupama Lakra, Jitendra Trivedi and Sunidhi Mishra. 2018. Studies on Biochemical Composition of Various Tomato (Solanum lycopersicum L.) Genotypes. Int.J.Curr.Microbiol.App.Sci. 7(12): 977-987. doi: https://doi.org/10.20546/ijcmas.2018.712.121 